\title{
Application of fluorescence in situ hybridisation to chromosome analysis of aged bone marrow
}

\section{smears}

\author{
D W Hammond, R F Hinchliffe, M H Goyns, A M Potter, J S Lilleyman
}

\begin{abstract}
Aims-To evaluate the reliability of fluorescence in situ hybridisation (FISH) in the retrospective cytogenetic assessment of old bone marrow smears stored for periods of up to 20 years.

Methods-A series of bone marrow smears either Romanowsky stained, or frozen and unstained, and aged from one month to 20 years were hybridised with biotin labelled probes specific for the centromeric regions of human chromosomes $X$, 6, and 18. Sites of hybridisation were detected with fluoresceinated avidin. One hundred to 400 cells from each preparation were examined and the number of signals observed was recorded.

Results-All smears exhibited signals in most cells examined. In cytogenetically normal cases, an average $67 \cdot 6 \%$ of cells (range 36\%-90\%) demonstrated the appropriate number of $X$ centromere signals. In those samples known to contain extra chromosomes $X, 6$, or 18 the presence of cells with the abnormal copy number was clearly detected in each case. Conclusion-When applied in the way described, FISH can give consistent and accurate results with a variety of archival bone marrow smears, including aged prestained material. This will permit retrospective assessment of specific cytogenetic abnormalities in patients with leukaemia using their initial diagnostic slides even where these are several years old.
\end{abstract}

(F Clin Pathol 1994;47:508-511)

The Institute for Cancer Studies and Department of Clinical Oncology, University of Sheffield Medical School D W Hammond M H Goyns

Section of Paediatric Haematology, University of Sheffield Department of Paediatrics, The Children's Hospital, Western Bank, Sheffield S10 2TH R F Hinchliffe J S Lilleyman

Centre for Human Genetics, Sheffield A M Potter

Correspondence to: Professor J S Lilleyman Accepted for publication 14 December 1993

Fluorescence in situ hybridisation (FISH) is currently being applied increasingly often as an adjunct to the conventional cytogenetic analysis of tumour cells. ${ }^{12}$ The technique has proved particularly useful when material for chromosome analysis is difficult to obtain or is of inadequate quality. Since the introduction of interphase cytogenetics by Cremer et $a l^{3}{ }^{3}$ probes containing chromosome centromeric regions, whole chromosome libraries, and cosmids have been successfully hybridised to interphase cells from both haematological malignancies and solid tumours. ${ }^{4-7}$

So far, most studies on haematological malignancies have been carried out either with cultured cells ${ }^{89}$ or on specially prepared uncultured material. ${ }^{10}$ As stored bone marrow smears are available in most haema- large and readily available pool of potential data on the incidence and clinical relevance of chromosome abnormalities in a wide range of leukaemias and lymphomas.

To evaluate the reliability of FISH on aged bone marrow slides, we applied a probe for the centromeric region of the $\mathrm{X}$ chromosome to a series of bone marrow smears. These were taken from patients with acute lymphoblastic leukaemia (ALL), diagnosed from months to years previously, in order to study the hybridisation efficiency and degree of background obtained in material of different ages. Centromere probes for chromosomes $\mathrm{X}$, 6 , and 18 were also hybridised to bone marrow smears obtained at diagnosis from patients found to have an abnormal karyotype by conventional cytogenetics, to assess the degree of concordance between results obtained by FISH and routine chromosome analysis.

\section{Methods}

Before processing, a myelogram was performed on each slide, or, if unfixed, on a stained slide collected at the same time. FISH was then attempted on bone marrow smears taken either when ALL was diagnosed or early during clinical remission. Slides had been either Romanowsky stained and mounted or were unfixed and stored in plastic film at $-20^{\circ} \mathrm{C}$. They ranged in age from one month to 20 years.

Cover slips were removed from old stained slides by immersion in xylene for up to 48 hours. The slides were then rinsed in fresh xylene, washed in $70 \%$ ethanol, and air dried. Unstained slides were also washed in $70 \%$ ethanol and air dried.

Before hybridisation, slides were treated tology departments, however, they represent a

with $10 \mu \mathrm{g} / \mathrm{ml}$ RNAse A (Boeringer Mannheim UK) in $2 \times$ saline sodium citrate (SSC), $\mathrm{pH} 7 \cdot 0$, for one hour at $37^{\circ} \mathrm{C}$, and then washed three times in $2 \times$ SSC. After incubation with $250 \mu \mathrm{g} / \mathrm{ml}$ pepsin (Sigma UK) in $0.01 \mathrm{M} \mathrm{HCl}$ at $37^{\circ} \mathrm{C}$, slides were washed twice in phosphate buffered saline (PBS), once in PBS/50 mM $\mathrm{MgCl}_{2}$, and then postfixed with $1 \%$ formaldehyde in $\mathrm{PBS} / \mathrm{MgCl}_{2}$. After a final wash in PBS, slides were dehydrated in an ethanol series $(70 \%, 95 \%, 100 \%)$ and air dried.

Biotinylated probes for the centromeric regions of chromosomes $\mathrm{X}, 6$, and 18 (Oncor; obtained from Alpha Laboratories, Eastleigh, Hants) at a final concentration of $1 \mathrm{ng} / \mu \mathrm{l}$ in $50 \%$ formamide, $10 \%$ dextran sulphate, and 1\% Tween-20 (Pierce and Warriner, Chester, England) were denatured at $75^{\circ} \mathrm{C}$ for five 
Table 1 Clinical and sample data and $X$ centromere probe FISH results for stored bone marrow smears obtained from children with $A L L$ in remission

\begin{tabular}{|c|c|c|c|c|c|c|c|}
\hline \multirow[b]{2}{*}{ Case No } & \multirow[b]{2}{*}{$\operatorname{Age}(y) / \operatorname{sex}$} & \multirow[b]{2}{*}{ Age of smear (months) } & \multirow[b]{2}{*}{ Type of smear* } & \multicolumn{4}{|c|}{ Percentage of cells with number of signals } \\
\hline & & & & 0 & 1 & 2 & 3 \\
\hline 1 & $5 / \mathrm{M}$ & 6 & $\mathbf{R M}$ & 26 & 72 & 2 & 0 \\
\hline 2 & $8 / \mathrm{M}$ & 6 & $\mathrm{RM}$ & 49 & $49 \cdot 5$ & 1.5 & 0 \\
\hline 3 & $8 / F$ & 6 & $\mathbf{R M}$ & 22.5 & 11 & 65 & 1.5 \\
\hline 4 & $4 / F$ & 12 & $\mathbf{R M}$ & 5 & 14 & 81 & 0 \\
\hline 5 & $2 / \mathrm{F}$ & 36 & $\mathrm{RM}$ & $23 \cdot 5$ & 18 & 56 & $2 \cdot 5$ \\
\hline 6 & $9 / \mathrm{F}$ & 240 & $\mathrm{RM}$ & 49 & 15 & 36 & 0 \\
\hline 7 & $15 / F$ & 120 & $\mathbf{R M}$ & 16 & 16 & 66 & 2 \\
\hline 8 & $3 / \mathrm{M}$ & 60 & $\mathrm{RM}$ & 21 & 74.5 & 4.5 & 0 \\
\hline \multirow[t]{2}{*}{9} & $5 / \mathrm{F}$ & 1 & $\mathbf{R M}$ & 1 & 6 & 90 & 3 \\
\hline & & & UF & 3 & 10 & 85 & 2 \\
\hline 10 & $6 / \mathrm{M}$ & 180 & $\mathbf{R M}$ & $40 \cdot 5$ & 58 & 1.5 & 0 \\
\hline
\end{tabular}

^RM Romanowsky stained and mounted; UF Unfixed, stored frozen

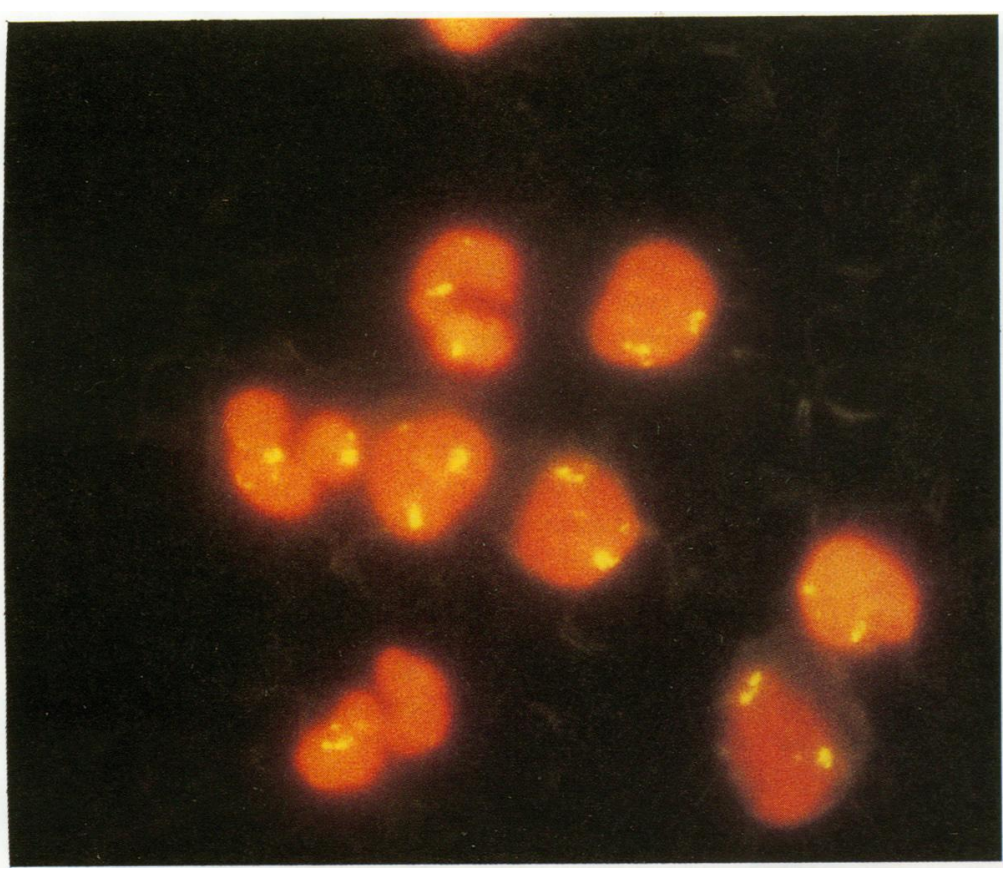

Figure 1 Hybridisation of an $X$ centromere probe to interphase nuclei on a 10 year old Romanowsky stained bone marrow smear from a female patient with $A L L$ in remission.

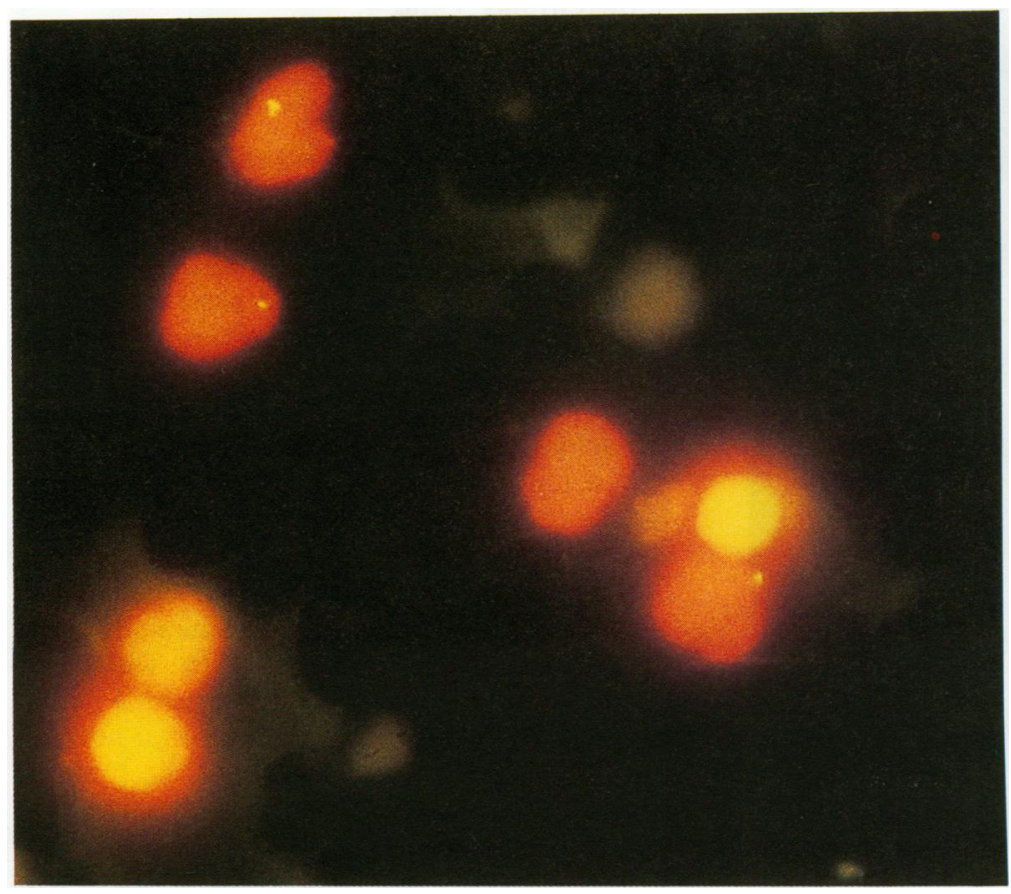

Figure 2 Hybridisation of an X centromere probe to interphase nuclei on a 15 year old Romanowsky stained bone marrow smear from a male patient with ALL in remission. minutes and kept on ice until used. Slides were denatured in $70 \%$ formamide $/ 2 \times \mathrm{SSC}$ at $70^{\circ} \mathrm{C}$ for two minutes, dehydrated in an icecold ethanol series, and air dried.

Probe mixture $(10 \mu \mathrm{l})$ were added to each slide, a coverslip applied, and the edges sealed with rubber solution. Hybridisation took place overnight at $37^{\circ} \mathrm{C}$ in a humid chamber. After removal of the coverslips, slides were washed three times for five minutes in $50 \%$ formamide, $2 \times \mathrm{SSC}(\mathrm{pH} 7 \cdot 0)$ at $42^{\circ} \mathrm{C}$, three times for five minutes in $2 \times \mathrm{SSC}$ at $42^{\circ} \mathrm{C}$ and in $4 \times$ SSC, $0.05 \%$ Tween-20 (pH 7.0) (SSCT) at room temperature for three minutes. A further incubation was carried out in SSCT containing $5 \%$ non-fat milk powder (with the solids spun out) under coverslips in a humid chamber for 10 minutes. After a final wash in SSCT the probe was detected by incubating with fluorescein isothiocyanate (FITC) conjugated avidin $(4 \mu \mathrm{g} / \mathrm{ml})$ (Vector Laboratories, Peterborough) at room temperature for 20 minutes. The signal was then amplified using the method of Pinkel et al, ${ }^{11}$ by incubating with biotinylated anti-avidin $(5 \mu \mathrm{g} / \mathrm{ml}$ ) (Vector) and a further layer of FITC-avidin.

After washing in PBS and dehydration in an ethanol series slides were mounted in AF1 (Citifluor Ltd, Canterbury, Kent) containing propidium iodide $(0.5 \mu \mathrm{g} / \mathrm{ml})$. Preparations were examined on a Leitz Laborlux 12 photomicroscope equipped for FITC epifluorescence and 100-400 interphase nuclei scored per slide for the presence of a signal or signals.

\section{Results}

Table 1 gives patient information, smear type, and age and the percentages of nuclei with different numbers of $\mathrm{X}$ centromere hybridisation signals for the series of patients in remission. The hybridisation efficiency ranged from $51-99 \%$ with an average of $76 \cdot 7 \%$. The oldest sample showed the lowest efficiency, and the most recent, the highest efficiency. A small percentage of nuclei demonstrated extra X centromere signals (two in males and three in females), with a mean of $1 \cdot 86^{+} 1 \cdot 21 \%$. Figures 1 and 2 illustrate hybridisation of the $X$ centromere probe to typical interphase nuclei from two smears stored for 10 and 15 years, respectively.

Table 2 gives details of the hybridisation of probes specific for the centromeric regions of 
Table 2 Clinical, sample, and cytogenetic data and FISH analysis on eight children with acute lymphoblastic leukaemia

\begin{tabular}{|c|c|c|c|c|c|c|c|c|c|c|c|c|}
\hline \multirow{2}{*}{$\begin{array}{l}\text { Case } \\
\text { No }\end{array}$} & \multirow[b]{2}{*}{ Age/sex } & \multirow{2}{*}{$\begin{array}{l}\text { Age of } \\
\text { smear (ms) }\end{array}$} & \multirow{2}{*}{$\begin{array}{l}\text { Type of } \\
\text { smear }\end{array}$} & \multirow{2}{*}{$\begin{array}{l}\text { Probe } \\
\text { specificity }\end{array}$} & \multicolumn{5}{|c|}{ Percentage of cells with number of signals } & \multirow{2}{*}{$\begin{array}{l}\text { Cytogenetic } \\
\text { abnormality }\end{array}$} & \multicolumn{2}{|l|}{ Mitoses } \\
\hline & & & & & 0 & 1 & 2 & 3 & 4 & & Examined & $\%$ abnormal \\
\hline $\begin{array}{l}11 \\
12 \\
13\end{array}$ & $\begin{array}{l}4 / F \\
2 / F \\
4 / M\end{array}$ & $\begin{array}{l}13 \\
42 \\
31\end{array}$ & $\begin{array}{l}\text { RM } \\
\text { UF } \\
\text { RM } \\
\text { UF }\end{array}$ & $\begin{array}{l}\underset{\mathbf{X}}{\mathbf{X}} \\
\mathbf{X} \\
\mathbf{X}\end{array}$ & $\begin{array}{l}4 \\
0 \\
2 \\
0\end{array}$ & $\begin{array}{r}8 \\
0 \\
18 \\
15\end{array}$ & $\begin{array}{l}31 \\
13 \\
78 \\
85\end{array}$ & $\begin{array}{r}57 \\
85 \\
2 \\
0\end{array}$ & $\begin{array}{l}0 \\
2 \\
0 \\
0\end{array}$ & $\begin{array}{l}\text { Trisomy } \mathbf{x} \\
\text { Trisomy } \mathbf{x} \\
\text { Disomy } \mathbf{x}\end{array}$ & $\begin{array}{l}12 \\
50 \\
14\end{array}$ & $\begin{array}{r}100 \\
50\end{array}$ \\
\hline 14 & $1 / \mathrm{F}$ & 75 & $\begin{array}{l}\text { RM } \\
\text { UF }\end{array}$ & $\begin{array}{l}6 \\
6\end{array}$ & $\begin{array}{r}11 \\
0\end{array}$ & $\begin{array}{r}29 \\
0\end{array}$ & $\begin{array}{l}30 \\
11\end{array}$ & $\begin{array}{l}30 \\
89\end{array}$ & $\begin{array}{l}0 \\
0\end{array}$ & Trisomy 6 & 24 & ס \\
\hline 15 & $9 / \mathrm{F}$ & 11 & $\begin{array}{l}\text { RM } \\
\text { UF }\end{array}$ & $\begin{array}{l}6 \\
6\end{array}$ & $\begin{array}{l}4 \\
0\end{array}$ & $\begin{array}{l}4 \cdot 5 \\
3\end{array}$ & $\begin{array}{l}91 \\
95\end{array}$ & $\begin{array}{c}4.5 \\
2\end{array}$ & $\begin{array}{l}0 \\
0\end{array}$ & $\begin{array}{l}\text { ?Small } \\
\operatorname{Der}(6)\end{array}$ & 28 & $\begin{array}{l}83 \\
61\end{array}$ \\
\hline 16 & $8 / M$ & 52 & UF & 18 & 2 & 10 & 73 & 15 & 0 & Trisomy 18 & 15 & \\
\hline 17 & $1 / \mathrm{F}$ & 76 & $\begin{array}{l}\text { RM } \\
\text { UF }\end{array}$ & $\begin{array}{l}18 \\
18\end{array}$ & $\begin{array}{c}26 \cdot 5 \\
0\end{array}$ & $\begin{array}{c}44 \cdot 5 \\
1\end{array}$ & $\begin{array}{l}18 \cdot 5 \\
21\end{array}$ & $\begin{array}{l}10 \cdot 5 \\
73\end{array}$ & $\begin{array}{l}0 \\
5\end{array}$ & Trisomy 18 & 24 & 83 \\
\hline 18 & $8 / \mathbf{M}$ & 76 & $\begin{array}{l}\text { RM } \\
\text { UF }\end{array}$ & $\begin{array}{l}18 \\
18\end{array}$ & $\begin{array}{c}16 \cdot 5 \\
0\end{array}$ & $\begin{array}{c}20 \cdot 5 \\
4\end{array}$ & $\begin{array}{l}34 \cdot 5 \\
24\end{array}$ & $\begin{array}{l}28 \\
67.5\end{array}$ & $\begin{array}{l}0.5 \\
4.5\end{array}$ & Trisomy 18 & 10 & 100 \\
\hline
\end{tabular}

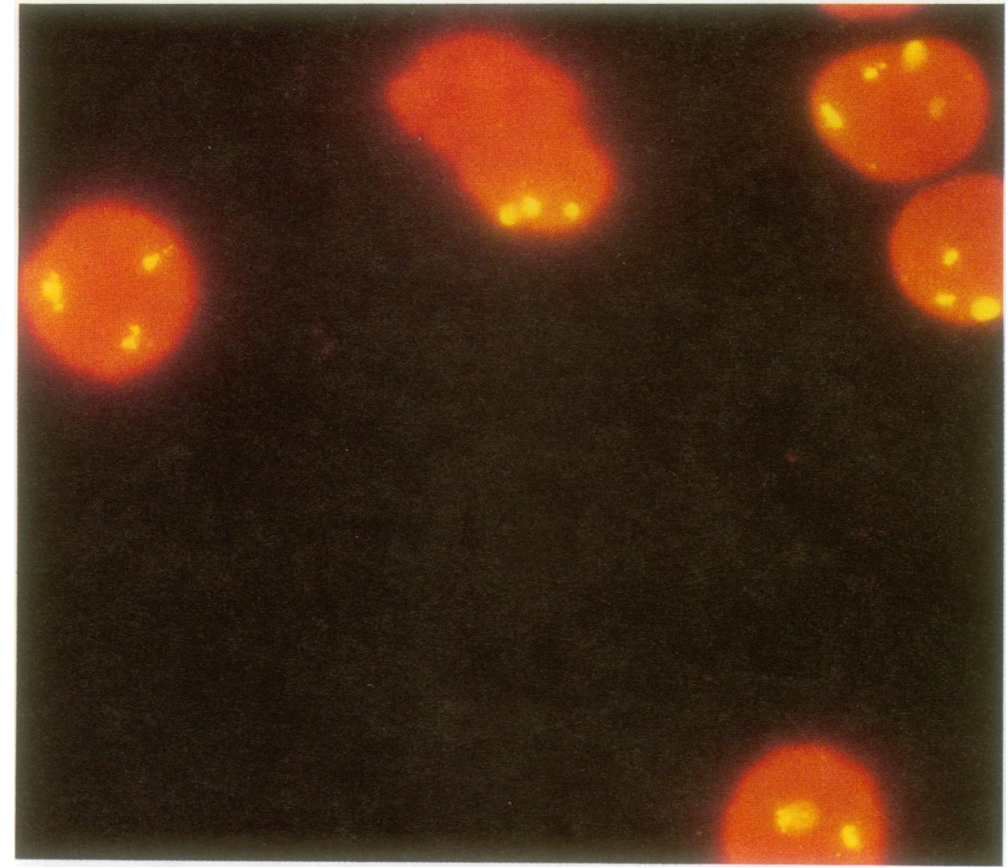

Figure 3 Hybridisation of a chromosome 6 centromere probe to interphase nuclei on a 6 year old unfixed bone marrow smear from a female patient with ALL at diagnosis. Trisomy of chromosome 6 had been shown by conventional cytogenetics.

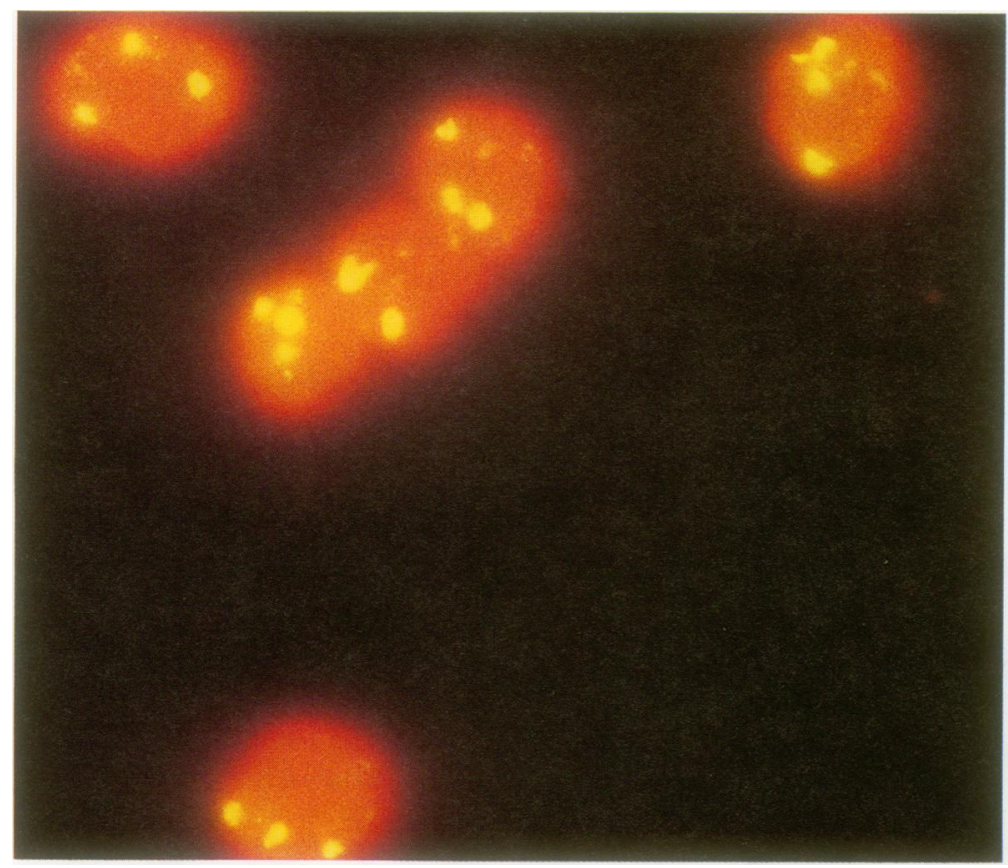

Figure 4 Hybridisation of an $X$ centromere probe to interphase nuclei on a $31 / 2$ year old unfixed bone marrow smear from a female patient with $A L L$ at diagnosis. Trisomy of chromosome $X$ had been shown by conventional cytogenetics. chromosomes $\mathrm{X}, 6$, and 18 to bone marrow smears from children with ALL. In this series of samples a hybridisation efficiency of between $76.5 \%$ and $100 \%$ was obtained, with the unfixed frozen material showing very few nuclei without signals. A trisomic clone was defined as being present in an ALL bone marrow smear when the percentage of nuclei displaying three signals was greater than the mean percentage $+(2 \times$ standard deviation $)$ of cells showing an extra signal in the remission samples, following the approach of Anastasi et al. ${ }^{12}$ When this criterion was applied to the ALL smears, all cases clearly showed the presence of extra copies of those chromosomes previously identified by conventional cytogenetics as aneusomic. Results from the unfixed material showed a closer correspondence with the proportion of abnormal cells found cytogenetically, than the results from Romanowsky stained slides.

In case 15 the data confirmed the identity of a marker thought to be derived from chromosome 6 and revealed the possible presence of a small clone containing three chromosome 6 centromeres. Representative hybridisations to interphase nuclei from two of the cases are shown in figs 3 and 4.

\section{Discussion}

DNA probes specific for the centromeric regions of a range of human chromosomes were hybridised to a series of archival bone marrow smears taken from children with ALL. Signals were observed in all cases examined, although a proportion of cells in most samples failed to exhibit detectable hybridisation.

In the remission series the hybridisation efficiency observed and the accuracy of the technique in identifying normal male and female cells was related to the age of the material, with the oldest performing least well and the freshest the best. In earlier work which applied FISH to bone marrow smears, the age of the material ranged from a few weeks ${ }^{12}$ to several years, ${ }^{13}$ the latter on unstained slides. Interestingly, those authors found no correlation between the storage time of the material and the extent to which hybridisation was successful.

The pyknotic nuclei of late erythroblasts might conceivably show reduced hybridisation efficiency and this may have contributed 
to the number of negative nuclei in remission samples. Although there was a correlation between the proportion of all erythroblasts and the proportion of negative nuclei in this material, it was not significant.

Numerical chromosomal abnormalities were detected in all of the ALL samples, with the proportion of cells displaying aneuploidy varying considerably from case to case. This reflected a mixed clonality within the samples, previously demonstrated by chromosome analysis, although there was not an exact correspondence between conventional and interphase cytogenetics. This discordance is probably due to the limitation of the conventional technique, whereby only small numbers of dividing cells can be studied. In contrast, the FISH technique can be applied to much larger numbers of interphase cells, and results are likely to reflect the relative proportions of different clones more accurately, as others have found. ${ }^{14}$

Discrepancies in hybridisation efficiency were also found between older paired Romanowsky stained and unfixed material from patients with ALL at diagnosis. This is illustrated in the results from case 17 (table 2), where some $60 \%$ of nuclei showed either one or no signals in the stained slide. Nevertheless, even in this material a clone of cells showing trisomy 18 was clearly detected.

Our results indicate that accurate information on chromosomal abnormalities can be obtained from routine bone marrow smears after many years in storage, including stained and mounted slides from patients who were diagnosed before chromosome banding techniques were widely available. ${ }^{15}$ Preliminary studies in our laboratory also suggest that cosmid probes can also be used for the detection of specific chromosome translocations on such archival material. The potential therefore exists for the rapid collection of retrospective data on rare chromosome changes in leukaemia for use in epidemiological and clinical studies.
DWH and MHG were supported by the Yorkshire Cancer Research Campaign.

RFH was supported by the Parents' Association of Children with Tumours and Leukaemia.

1 Poddighe PJ, Moesker O, Smeets D, Awwad BH, Ramaekers FCS, Hopman AHN. Interphase cytogenetics of haematological cancer: comparison of classical
karyotyping and in situ hybridization using a panel of eleven chromosome specific probes. Cancer Res 1991; 51:1959-67.

2 Tkachuk DC, Pinkel D, Kuo W-L, Weier H-U, Gray JW. Clinical applications of fluorescence in situ hybridisation. GATA 1991;8:67-74.

3 Cremer T, Landegent J, Bruckner A, School $\mathrm{H}$, Schardin $M$, Hager $\mathrm{H}$, et al. Detection of chromosome aberrations in the human interphase nucleus by visualization of specific target DNAs. Hum Genet 1986;74;346-52.

4 Arnoldus EPJ, Wiegant J, Noordermeer IA, Wessells JW, Beverstock GC, Grosveld GC, et al. Detection of the Philadelphia chromosome in interphase nuclei. Cytogenet Cell Genet 1990;54:108-11.

5 Arnoldus EPJ, Noordermeer IA, Boudawijn Peters AC, Voormolen JHC, Bots GTAM, Raap AK, et al. Interphase cytogenetics of brain tumors. Genes Chrom Cancer 1991;3:101-7.

6 Kiechle-Schlwarz M, Decker H-JH, Berger CS, Fiebig $\mathrm{HH}$, Sandberg AA. Detection of monosomy in interphase nuclei and identification of marker chromosomes phase nuclei and identification of marker chromosomes
using biotinylated alpha-satellite DNA probes. Cancer using biotinylated alpha-satellite
Genet Cytogenet 1991;21:23-33.

7 Brothman AR, Patel AM, Peehl DM, Schellhammer PF. Analysis of prostatic tumor cultures using fluorescence in-situ hybridization (FISH). Cancer Genet Cytogenet 1992;62:180-5.

8 Stanley WS, Devine GC, Murphy BA, Seibel N, Dinndorf $P$. Longitudinal cytogenetic study of metaphase and interphase cells in childhood monosomy 7 syndrome. Cancer Genet Cytogenet 1992;62:160-5.

9 Heerema NA, Argyropoulos G, Weetman R, Tricot G, Secker-Walker LM. Interphase in situ hybridisation reveals minimal residual disease in early remission and reveals minimal residual disease in early remission and return of the diagnostic clone in karyotypically normal
relapse of acute lymphoblastic leukaemia. Leukaemia relapse of acute

10 Kibbelaar RE, van Kamp H, Dreef EJ, Wessels JW, Beverstock GC, Raap AK, et al. Detection of trisomy 8 in hematological disorders by in situ hybridization. Cytogenet Cell Genet 1991;56:132-6.

11 Pinkel D, Straume T, Gray JW. Cytogenetic analysis using quantitative high sensitivity fluorescence hybridization. Proc Natl Acad Sci USA 1986;83:2934-8.

12 Anastasi J, Vardiman JW, Rudinsky R, Patel M, Nachman $\mathrm{J}$, Rubin CM, et al. Direct correlation of cytogenetic findings with cell morphology using in situ hybridization: an analysis of suspicious cells in bone marrow specimens an analysis of suspicious cells in bone marrow specimens of two patients completing therapy for ac
phoblastic lymphoma. Blood 1991;77:2456-62.

13 Lee W, Han K, Drut RM, Harris CP, Meisner LF. Use of fluorescence in situ hybridization for retrospective detection of aneuploidy in multiple myeloma. Genes Chrom Cancer 1993;7:137-43

14 Anastasi J, Le Beau MM, Vardiman JW, Fernald AA, Larson RA, Rowley JD. Detection of trisomy 12 in chronic lymphocytic leukaemia by flourescence in situ hybridization to interphase cells: a simple and sensitive method. Blood 1992;79:1796-801.

15 Seabright $M$. A rapid banding technique for human chromosomes. Lancet 1971;ii:971-2. 